Sains Malaysiana 49(2)(2020): 343-348

http://dx.doi.org/10.17576/jsm-2020-4902-12

\title{
Validity and Reliability of External Apical Root Resorption (EARR) Measurements: A 3D Cone Beam Computed Tomography (CBCT) Study
}

(Kesahihan dan Kebolehpercayaan Resorpsi Akar Apikal Luaran (EARR): Kajian Tiga Dimensi (3D) Komputer Kon Tomografi (CBCT))

FAZAL Shahid, Shifat A Nowrin, NORMa Ab RAHMAN* \& SAIDi JAAFAR

\section{ABSTRACT}

The purpose of this study was to evaluate the validity and reliability of external apical root resorption (EARR) measurements on commercial and open source software. The data sources were CBCT high volumetric data acquisition from the Malay ethnic group who are undergoing orthodontic treatment in School of Dental Sciences, Universiti Sains Malaysia. A total of 16 CBCT radiograph with 512 variables were measured using the Planmeca Romexis TM Software 2.3.1.R (Helsinki, Finland) and 3D Slicer v. 4.8 .1 (open-source software, http://www.slicer.org). Two examiners (A and $B)$ carried out all the measurements of the selected radiographs using the two softwares. Intra class correlation (ICC) coefficient test was applied to check the validity and reliability of EARR measurements. The validity of the 3D EARR measurements from both examiners $A$ and $B$ showed strong correlations. Moreover, ICC co-efficient values of inter examiner $A$ and $B$ were all in the range of strong correlation for EARR measurements in which reliability coefficient values were comparable with the measurements using Planmeca Romexis and 3D Slicer, respectively. All ICC coefficient values were positively correlated. Linear measurements of EARR using 3D CBCT in both commercial and open source software and are valid and reliable.

Keywords: External apical root resorption (EARR); reliability; validity; 3D cone beam computed tomography (CBCT)

\section{ABSTRAK}

Tujuan kajian ini adalah untuk menilai kesahihan dan kebolehpercayaan pengukuran resorpsi akar apikal luaran (EARR) antara perisian komersial dan sumber terbuka. Sumber adalah daripada data volumetrik sinaran-kon-tomografiberkomputer (CBCT) tiga dimensi (3D) dari kumpulan etnik Melayu yang menjalani rawatan ortodontik di Pusat Pengajian Sains Pergigian, Universiti Sains Malaysia. Sebanyak 16 radiografi CBCT dengan 512 pemboleh ubah diukur dengan menggunakan Perisian Planmeca Romexis TM 2.3.1.R (Helsinki, Finland) dan 3D Slicer v. 4.8.1 (perisian sumber terbuka, http://www.slicer.org). Dua pemeriksa (A dan B) melakukan semua ukuran radiografi terpilih menggunakan dua jenis perisian yang berbeza. Ujian koefisien korelasi kelas (ICC) digunakan untuk memeriksa kesahihan pengukuran EARR. Kesahihan pengukuran 3D EARR untuk pemeriksa A dan B menunjukkan korelasi yang kuat. Selain itu, nilai pekali ICC untuk pemeriksa antara A dan B semuanya berada dalam julat hubungan yang kuat untuk pengukuran EARR dengan nilai pekali kebolehpercayaan adalah setanding antara pengukuran menggunakan Planmeca Romexis dan 3D Slicer. Semua nilai koefisien ICC menunjukkan korelasi yang positif. Pengukuran linear EARR menggunakan 3D CBCT antara perisian komersial dan sumber terbuka adalah sah dan boleh dipercayai.

Kata kunci: Kebolehpercayaan; kesahihan; resorpsi akar apical luaran (EARR); sinaran-kon-tomografi-berkomputer (CBCT) tiga dimensi (3D)

\section{INTRODUCTION}

Successful orthodontic treatment requires detailed investigative evidence and comprehensive analysis. Assessing the root resorption is an essential part of orthodontic investigations as in some cases it may compromise the result of successful treatment (Nowrin et al. 2018). Different types of root resorption can be assessed precisely in different kind of radiographs. Orthopantamogram (OPG) and lateral cephalogram are widely used as a diagnostic radiograph in terms of orthodontic treatment. However, panaromic radiographs has disadvantages of its artefact especially in anterior root region. Moreover, detecting root resorption through the lateral cephalogram is limited due to the super-impositioning of the teeth (Leach et al. 2001; Md Mashfique \& Mohammad Khursheed 2017). To restrain these drawbacks, cone beam computed tomography $(\mathrm{CBCT})$ is the best option to assess root length (Lund et al. 2010; Yu et al. 2013). In late 1990's CBCT has been introduced to dentistry and its low radiation doses, affordability and high spatial resolution has directed to its acceptance in orthodontics (Arai et al. 1999; Mozzo et al. 1998; Palomo et al. 2006). CBCT radiographs are distortion 
free and its reproducible images of single root has the advantages of clear landmarks at different magnifications and accurate cross-sectional images (Lund et al. 2010; Roscoe et al. 2015).

Assessment of root resorption on $\mathrm{CBCT}$ radiograph has been performed in different studies (Leach et al. 2001; Lund et al. 2010; Mohandesan et al. 2007). However, all the assessments performed in the aforementioned studies were proprietary or belongs to the commercial software package thus can only be used after purchasing the software with huge budgets. Commercial software is usually limited for few users and specific gadget. In addition, nowadays, different open source software is easily accessible without using any budget of purchasing to perform the desire measurements for the benefit of patients or research purposes. To the best of our knowledge, no studies has been performed to evaluate the root length area using an open source software which is find in webpages with free of charge.

Therefore, the purpose of this study was to evaluate the validity and reliability of external apical root resorption (EARR) measurements on both commercial and open source software named Planmeca Romexis TM Software 2.3.1.R and 3D slicer v. 4.8.1, respectively.

\section{MATERIALS AND METHODS}

Eight patients (seven females and one male, ages from 18 to 22 years) were selected for this study. All the patients were receiving orthodontic treatment with premolar extraction. The CBCT images of the patients were obtained before and after leveling- alignment stage (average 7 months) of orthodontic treatment. All CBCT images were acquired using the following specifications: $90 \mathrm{kVp}, 320$ $\mu \mathrm{m}$ voxel resolution, $12 \mathrm{~mA}$. Orthodontic treatment was conducted by the same orthodontist with fixed appliances bonded until 2nd molars. All patients were reviewed with 4 weeks' intervals. Sequences of wires were as followed: $0.014 \mathrm{NiTi}, 0.016 \mathrm{NiTi}, 0.018 \mathrm{NiTi}, 0.017 \times 0.025 \mathrm{NiTi}$ and $0.019 \times 0.025 \mathrm{NiTi}$ size of arch wire on a 0.022 -inch slot until the leveling- alignment stage of treatment. Ethical approval was obtained from the Human Research and Ethics Committee (HREC), Universiti Sains Malaysia USM/ JEPeM/15020074.

\section{MEASUREMENT PROCEDURE}

CBCT was used to assess all anterior and molars teeth of 8 patients using the crown and root height in 16 radiographs. With the help of DICOM export, 3D images were constructed in acquisition softwares Planmeca Romexis TM Software 2.3.1.R (Helsinki, Finland) and 3D Slicer v. 4.8.1 (open-source software, http://www.slicer.org). All the teeth except premolars (due to extraction) and 3rd molars were measured. To measure the tooth length, all the teeth were divided in crown and root portion. Cemento enamel junction (CEJ) was taken as a guideline to divide the teeth (Figure 1). A correction factor (CF) was calculated for crown length as crown length should be unchanged over the observation period. The following formula was used to determine the EARR from the CBCT images:

$$
\mathrm{EARR}=\mathrm{R}_{1}-\left(\mathrm{R}_{2} \times \mathrm{CF}\right) ; \mathrm{CF}=\mathrm{C}_{1} / \mathrm{C}_{2}
$$

where $R_{1}$ is the initial root length; $R_{2}$ is the root length after leveling alignment stage; $\mathrm{C}_{1}$ is the initial crown length; $\mathrm{C}_{2}$ is the crown length after leveling alignment stage; and $\mathrm{CF}$ is the correction factor.

Two investigators (A and $\mathrm{B}$ ) carried out all the EARR measurement in both Romexis (Figures 2 \& 3) and 3D

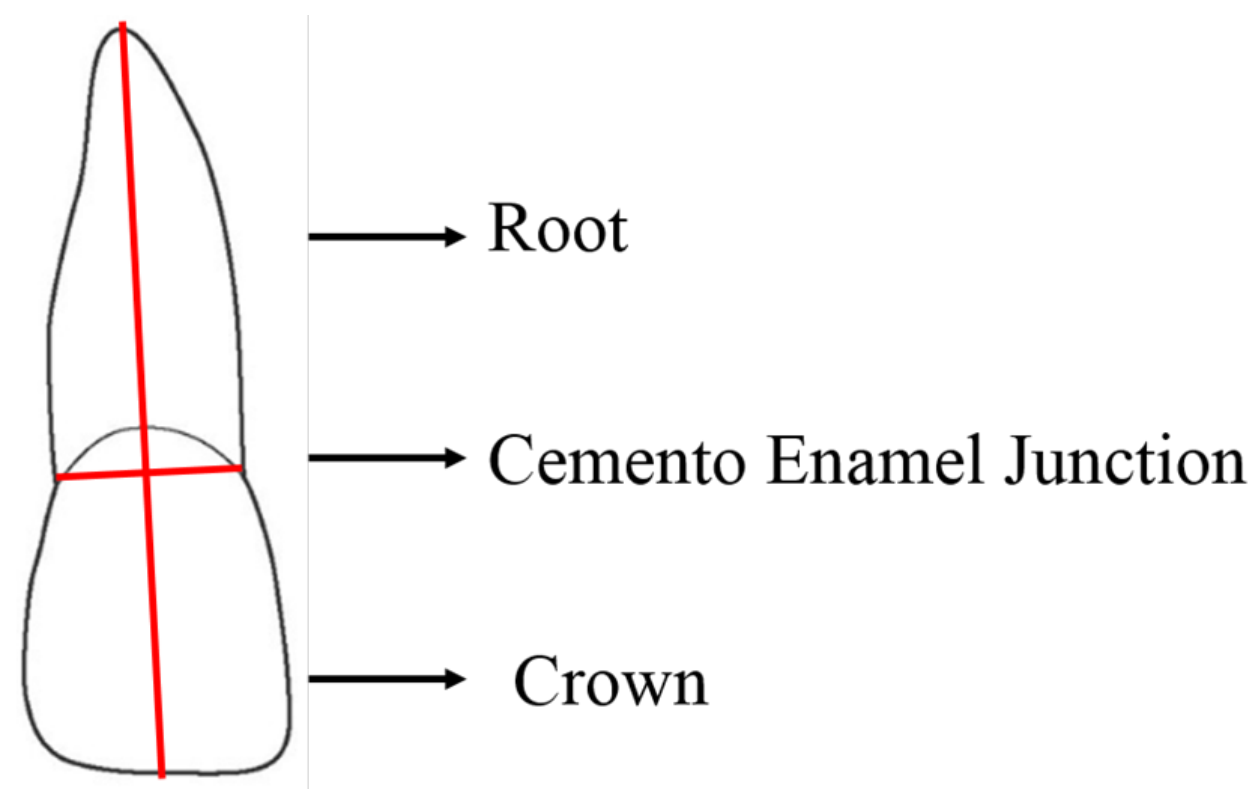

FIGURE 1. Measurements of tooth by dividing with cemento-enamel junction (CEJ) 


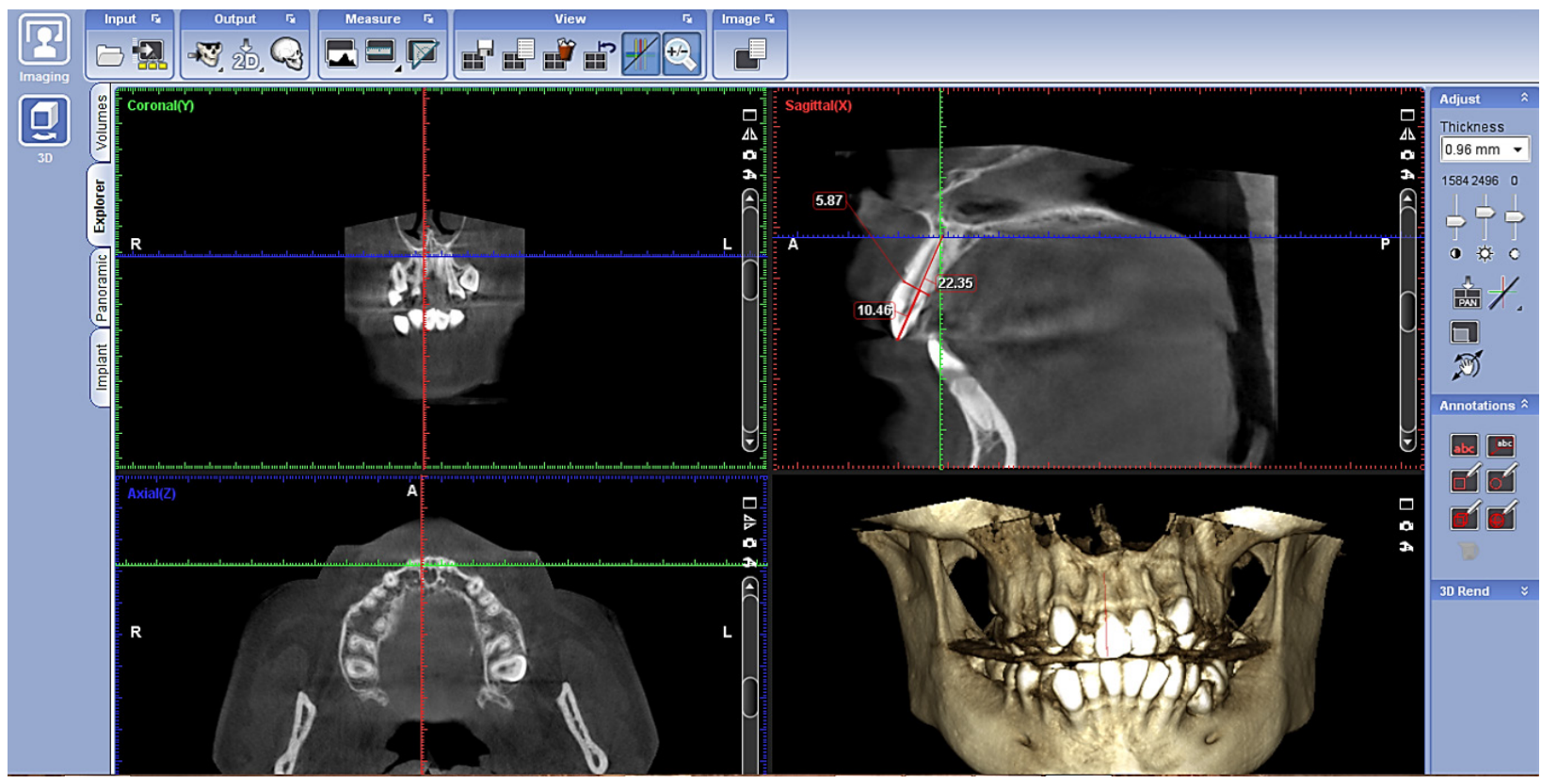

FIGURE 2. Measurements of pre cone beam computed tomography (CBCT) image using Romexis software

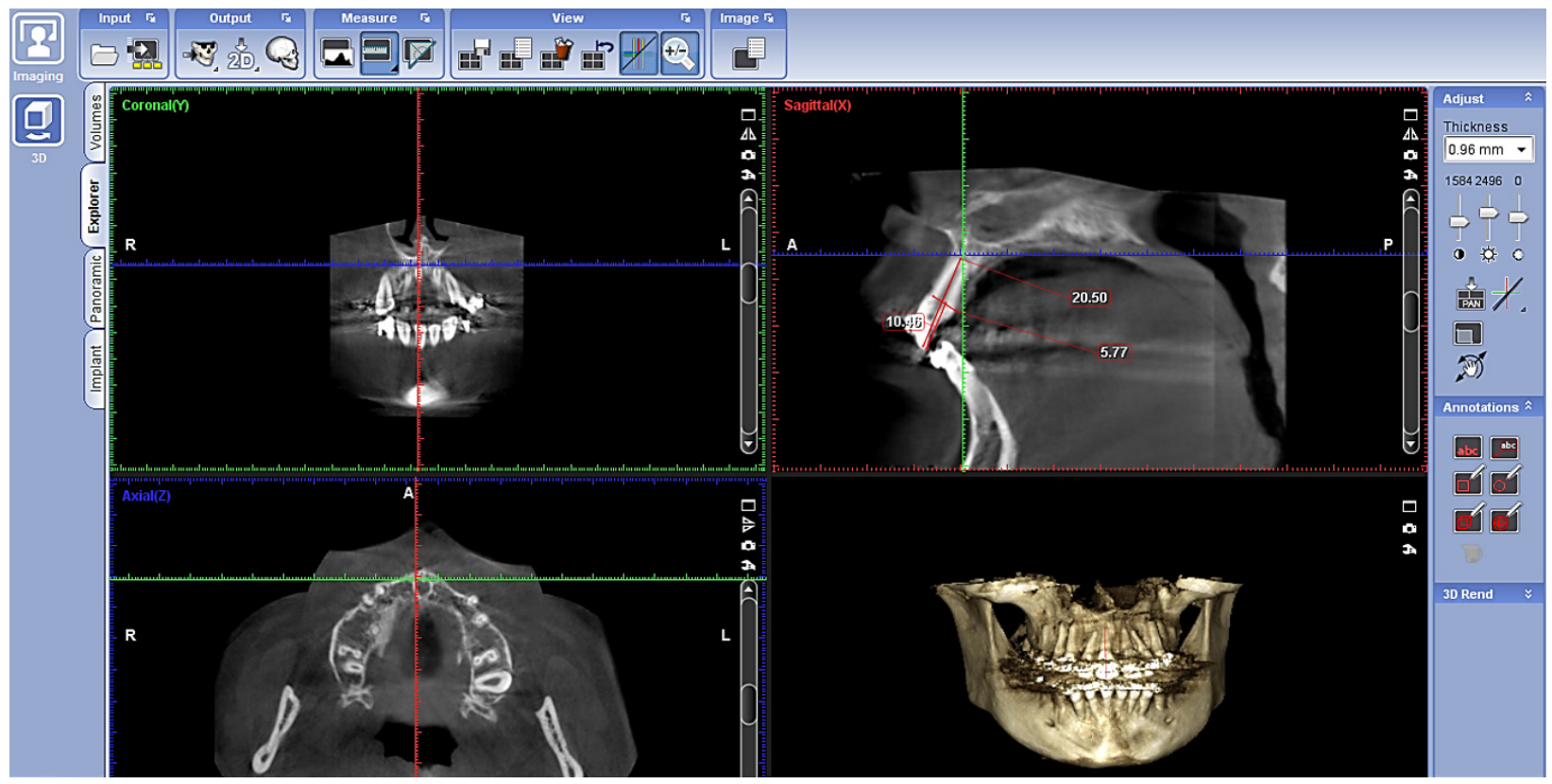

FIGURE 3. Measurements of cone beam computed tomography (CBCT) image after levelling and alignment stage using Romexis software

slicer software (Figures 4 \& 5). Interrater agreement is considered as excellent if the value of ICC is $0.75-1$, good if ICC is $0.60-0.74$, fair if ICC is $0.40-0.59$, and poor if ICC is less than 0.40 (Cicchetti 1994).

\section{STATISTICAL ANALYSIS}

All the statistical analyses were performed using SPSS version 22.0 (Chicago, USA). Measurements of validity and reliability were statistically assessed using intra class correlation coefficient (ICC). The validity of 3D measurements was analyzed with ICC between $3 \mathrm{D}$ slicer values and Romexis value. ICC was performed to examine inter- examiner measurement reliability.

\section{RESULTS}

Tables 1 and 2 show the validity of 3D EARR measurements from intra examiners $A$ and $B$ which exhibited the values of coefficient were in range of strong correlation. Moreover, for inter examiner A and B, ICC co-efficient values also showed an excellent correlation for EARR measurements for both Planmeca Romexis and 3D Slicer software (Tables $2 \& 4)$. 


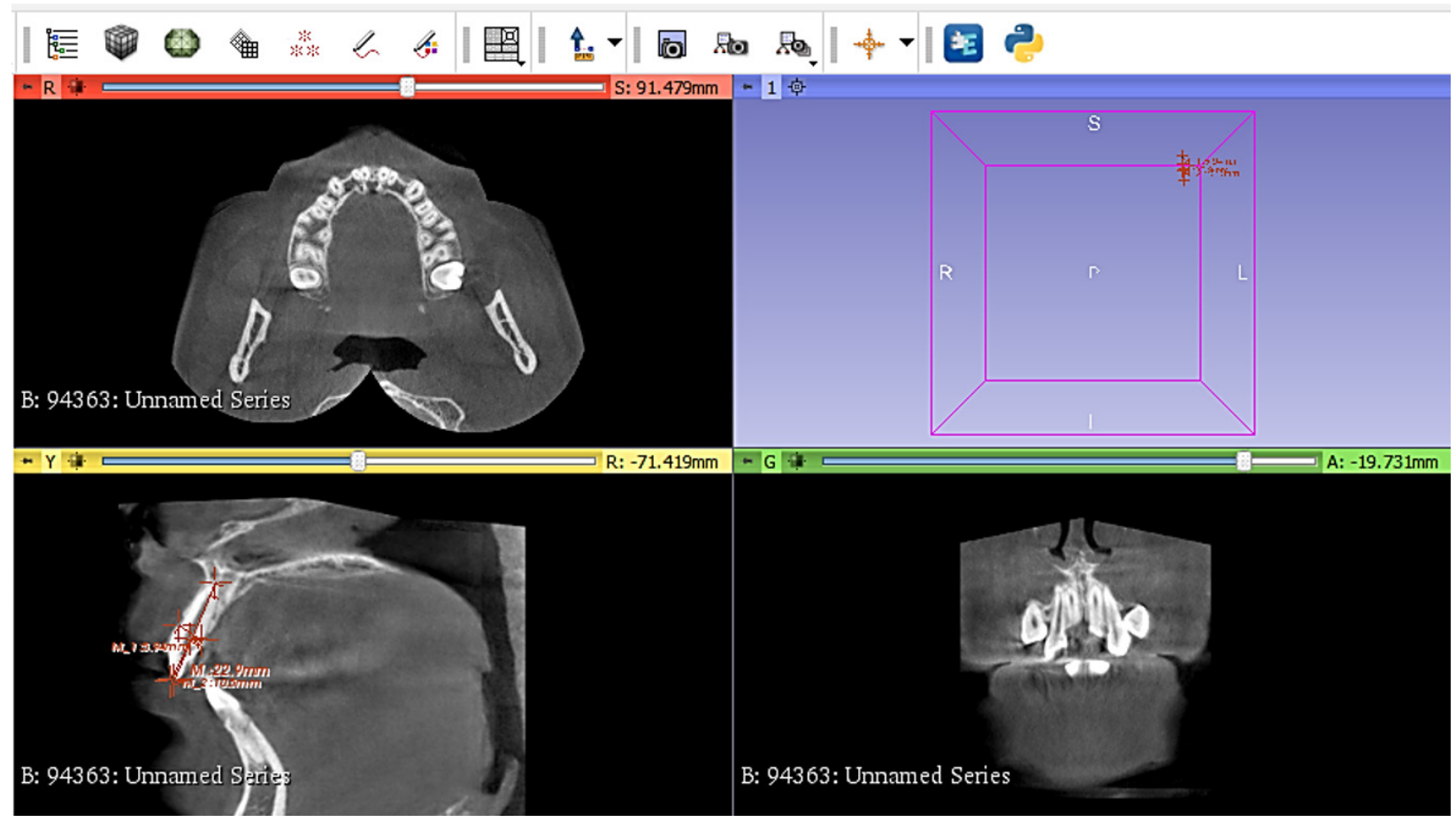

FIGURE 4. Measurements of pre cone beam computed tomography (CBCT) image using 3D Slicer software

TABLE 1. Validity of external apical root resorption (EARR) measurement for examiner A

\begin{tabular}{cccc}
\hline $\begin{array}{c}\text { Variables } \\
\text { (EARR)* }\end{array}$ & Coefficient & $\begin{array}{c}\text { Variables } \\
\text { (EARR)* }\end{array}$ & Coefficient \\
\hline Rx 11/ 3DS 11 & 0.979 & $R x$ 31/ 3DS 31 & 0.980 \\
Rx 12/ 3DS 12 & 0.951 & Rx 32/ 3DS 32 & 0.853 \\
Rx 13/ 3DS 13 & 0.999 & Rx 33/ 3DS 33 & 0.971 \\
Rx 16/ 3DS 16 & 0.980 & $R x$ 36/ 3DS 36 & 0.908 \\
Rx 21/ 3DS 21 & 0.985 & $R x$ 41/ 3DS 41 & 0.928 \\
Rx 22/ 3DS 22 & 0.880 & $R x$ 42/ 3DS 42 & 0.952 \\
Rx 23/ 3DS 23 & 0.985 & $R x$ 43/ 3DS 43 & 0.966 \\
Rx 26/ 3DS 26 & 0.906 & $R x$ 46/ 3DS 46 & 0.819 \\
\hline
\end{tabular}

*FDI notation; Rx,Romexis; 3DS, 3D Slicer

TABLE 2. Validity of external apical root resorption (EARR) measurement for Examiner B

\begin{tabular}{|c|c|c|c|}
\hline $\begin{array}{l}\text { Variables } \\
\text { (EARR)* }\end{array}$ & Coefficient & $\begin{array}{l}\text { Variables } \\
\text { (EARR)* }\end{array}$ & Coefficient \\
\hline Rx 11/3DS 11 & 0.971 & Rx 31/ 3DS 31 & 0.987 \\
\hline Rx 12/3DS 12 & 0.988 & Rx 32/ 3DS 32 & 0.832 \\
\hline Rx 13/3DS 13 & 0.998 & Rx 33/ 3DS 33 & 0.995 \\
\hline Rx 16/3DS 16 & 0.964 & Rx 36/ 3DS 36 & 0.956 \\
\hline Rx 21/3DS 21 & 0.989 & Rx 41/ 3DS 41 & 0.963 \\
\hline Rx 22/ 3DS 22 & 0.971 & Rx 42/ 3DS 42 & 0.964 \\
\hline Rx 23/3DS 23 & 0.993 & Rx 43/ 3DS 43 & 0.964 \\
\hline Rx 26/3DS 26 & 0.799 & Rx 46/ 3DS 46 & 0.765 \\
\hline
\end{tabular}

*FDI notation; Rx,Romexis; 3DS, 3D Slicer
TABLE 3. Inter examiner (A-B) external apical root resorption (EARR) measurement using Romexis

\begin{tabular}{cccc}
\hline $\begin{array}{c}\text { Variables } \\
\text { (EARR)* }\end{array}$ & Coefficient & $\begin{array}{c}\text { Variables } \\
\text { (EARR)* }\end{array}$ & Coefficient \\
\hline 11 & 0.990 & 31 & 0.983 \\
12 & 0.997 & 32 & 0.988 \\
13 & 0.998 & 33 & 0.978 \\
16 & 0.955 & 36 & 0.963 \\
21 & 0.984 & 41 & 0.933 \\
22 & 0.997 & 42 & 0.960 \\
23 & 0.987 & 43 & 0.977 \\
26 & 0.722 & 46 & 0.933 \\
\hline
\end{tabular}

*FDI notation

TABLE 4. Inter examiner (A-B) external apical root resorption (EARR) measurement using 3D Slicer

\begin{tabular}{cccc}
\hline $\begin{array}{c}\text { Variables } \\
(\text { EARR)* }\end{array}$ & Coefficient & $\begin{array}{c}\text { Variables } \\
(\text { EARR)* }\end{array}$ & Coefficient \\
\hline 11 & 0.974 & 31 & 0.998 \\
12 & 0.984 & 32 & 0.862 \\
13 & 1.000 & 33 & 0.994 \\
16 & 0.989 & 36 & 0.968 \\
21 & 0.994 & 41 & 0.977 \\
22 & 0.947 & 42 & 0.962 \\
23 & 0.986 & 43 & 0.987 \\
26 & 0.826 & 46 & 0.977 \\
\hline
\end{tabular}

*FDI notation 


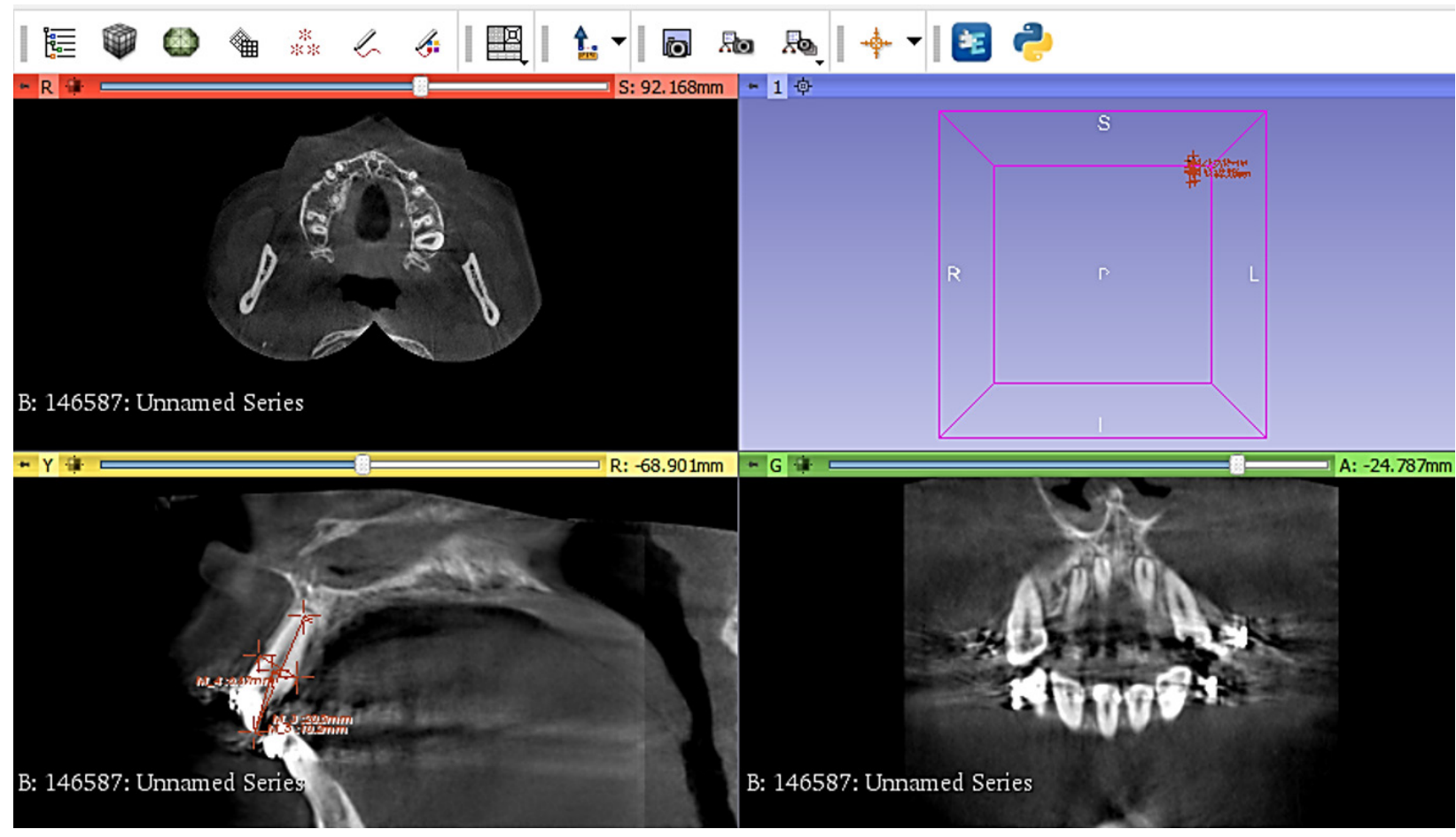

FIGURE 5. Measurements of cone beam computed tomography (CBCT) image after levelling and alignment stage using 3D Slicer software

\section{DISCUSSION}

To the best of our knowledge, no study has appraised the validity and reliability of linear EARR measurements on any open source software. The dicom format of 3D CBCT measurements showed no differences in EARR measurements for each of the variable measured. Measurements in 3D slicer were similar to the measurements in Planmeca Romexis software. Several studies have performed the EARR measurements in different commercial software (Castro et al. 2012; Lund et al. 2010; Yu et al. 2013). However, the validity in EARR measuements have never been assessed with any open source software.

Current study included an open source image analysis software. Commercial software packages for instance, i-CAT machine (Imaging Sciences International, Hatfield, PA, USA) (Yu et al. 2013), Maxilim (Medicim, Mechelen, Belgium) (Swennen et al. 2009), in vivo (Anatomage, San Jose, CA) (Luu et al. 2014) can yield adequate surface reconstruction, voxel-based registration and/or positioning adequate landmark, however these are not open source software. Furthermore, modification is difficult, do not offer flexibility for customization, and most importantly pre and post measurement of the same patients in different facial morphology or 3D correspondence problems were not addressed properly (Schilling et al. 2013). Due to the development of open source software, 3D image analysis is becoming different as it was a decade ago. Recently, medical image analysis has become available as open source for interventional management and image processing. Moreover, 3D Slicer became popular for radiological applications due to the open source facility. $3 \mathrm{D}$ image volume rendering, visualization and registration are handier and powerful in 3D Slicer v.4.8.1. All this open source software contributes meaningfully in the medical field and should have probable applications in dentistry as well.

\section{CONCLUSION}

Linear measurements of EARR using 3D CBCT in both commercial and open source software are valid and reliable. Open source 3D Slicer software is a valid tool to be used for measurements of EARR, besides it can also be used for various clinical orthodontic procedure (for instance, root resorption, bone density, tooth movement, tooth size analysis, arch length discrepancies, mixed dentition analysis study) even if any commercial software are not available for research.

\section{ACKNOWLEDGEMENTS}

Vice chancellor award 2016 and Graduate assistant scheme.

\section{REFERENCES}

Arai, Y., Tammisalo, E., Iwai, K., Hashimoto, K. \& Shinoda, K. 1999. Development of a compact computed tomographic apparatus for dental use. Dentomaxillofacial Radiology 28(4): 245-248.

Castro, I.O., Alencar, A.H.G., Valladares-Neto, J. \& Estrela, C. 2012. Apical root resorption due to orthodontic treatment detected by cone beam computed tomography. The Angle Orthodontist 83(2): 196-203. 
Cicchetti, D.V. 1994. Guidelines, criteria, and rules of thumb for evaluating normed and standardized assessment instruments in psychology. Psychological Assessment 6(4): 284-290.

Leach, H.A., Ireland, A.J. \& Whaites, E.J. 2001. Radiology: Radiographic diagnosis of root resorption in relation to orthodontics. British Dental Journal 190(1): 16-22.

Lund, H., Gröndahl, K. \& Gröndahl, H.G. 2010. Cone beam computed tomography for assessment of root length and marginal bone level during orthodontic treatment. Angle Orthodontist 80(3): 466-473.

Luu, N.S., Mandich, M.A., Flores-Mir, C., El-Bialy, T., Heo, G., Carey, J.P. \& Major. P.W. 2014. The validity, reliability, and time requirement of study model analysis using cone-beam computed tomography-generated virtual study models. Orthodontics \& Craniofacial Research 17(1): 14-26.

Md Mashfique Jamil \& Mohammad Khursheed Alam. 2017. Orthodontic treatment induced root resorption: A review. International Medical Journal 24(4): 330-332.

Mohandesan, H., Ravanmehr, H. \& Valaei, N. 2007. A radiographic analysis of external apical root resorption of maxillary incisors during active orthodontic treatment. The European Journal of Orthodontics 29(2): 134-139.

Mozzo, P., Procacci, C., Tacconi, A., Tinazzi Martini, P. \& Bergamo Andreis, I.A. 1998. A new volumetric CT machine for dental imaging based on the cone-beam technique: Preliminary results. European Radiology 8(9): 1558-1564.

Nowrin, S.A., Jaafar, S., Ab Rahman, N., Basri, R., Alam, M.K. \& Shahid, F. 2018. Association between genetic polymorphisms and external apical root resorption: A systematic review and meta-analysis. The Korean Journal of Orthodontics 48(6): 395-404.

Palomo, J.M., Chung H Kau., Palomo, L. \& Hans, M.G. 2006. Three-dimensional cone beam computerized tomography in dentistry. Dentistry Today 25(11): 130.

Roscoe, M.G., Meira, J.B.C. \& Cattaneo, P.M. 2015. Association of orthodontic force system and root resorption:
A systematic review. American Journal of Orthodontics and Dentofacial Orthopedics 147(5): 610-626.

Schilling, J., Gomes, L.C.R., Benavides, E., Nguyen, T., Paniagua, B., Styner, M., Gonçalves, V.B.J.R. \& Cevidanes, L.H.S. 2013. Regional 3D superimposition to assess temporomandibular joint condylar morphology. Dentomaxillofacial Radiology 43(1): 20130273.

Swennen, G.R.J., Mollemans, W., De Clercq, C., Abeloos, J., Lamoral, P., Lippens, F., Neyt, N., Casselman, J. \& Schutyser, F. 2009. A cone-beam computed tomography triple scan procedure to obtain a three-dimensional augmented virtual skull model appropriate for orthognathic surgery planning. Journal of Craniofacial Surgery 20(2): 297-307.

Yua, J-H., Shu, K-W., Tsai, M-T., Hsu, J-T., Chang, H-W. \& Tung, K-L. 2013. A cone-beam computed tomography study of orthodontic apical root resorption. Journal of Dental Sciences 8(1): 74-79.

Fazal Shahid, Shifat A Nowrin \& Norma Ab Rahman* Orthodontic Unit

School of Dental Sciences, Health Campus

Universiti Sains Malaysia

16150 Kubang Kerian, Kelantan Darul Naim

Malaysia

Saidi Jaafar

Craniofacial Biology Research Group

School of Dental Sciences, Health Campus

Universiti Sains Malaysia

16150 Kubang Kerian, Kelantan Darul Naim

Malaysia

*Corresponding author; email: drnorma@usm.my

Received: 18 November 2018

Accepted: 25 October 2019 